\title{
Effect of pre-in vitro maturation with cAMP modulators on the acquisition of oocyte developmental competence in cattle
}

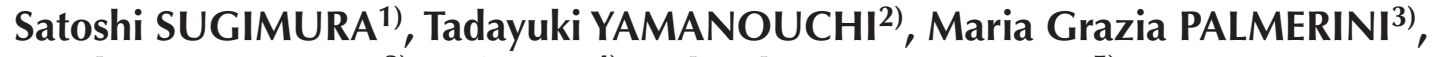 \\ Yutaka HASHIYADA ${ }^{2)}$, Kei IMAI ${ }^{4)}$ and Robert B GILCHRIST ${ }^{5)}$ \\ 1) Department of Biological Production, Institute of Agriculture, Tokyo University of Agriculture and Technology, \\ Tokyo 183-8509, Japan \\ 2) National Livestock Breeding Center, Fukushima 961-8511, Japan \\ ${ }^{3)}$ Department of Life, Health and Environmental Sciences, University of L'Aquila, L'Aquila 67100, Italy \\ 4) Department of Sustainable Agriculture, Rakuno Gakuen University, Hokkaido 069-8501, Japan \\ 5) Discipline of Obstetrics \& Gynaecology, School of Women's \& Children's Health, University of New South Wales, \\ Sydney 2052, Australia
}

\begin{abstract}
The administration of follicle-stimulating hormone (FSH) prior to oocyte retrieval improves oocyte developmental competence. During bovine embryo production in vitro, however, oocytes are typically derived from FSH-unprimed animals. In the current study, we examined the effect of pre-in vitro maturation (IVM) with cAMP modulators, also known as the second messengers of FSH, on the developmental competence of oocytes derived from small antral follicles (2-4 mm) of FSH-unprimed animals. Pre-IVM with N6,2'-O-dibutyryladenosine 3',5'-cyclicmonophosphate (dbcAMP) and 3-isobutyl-1methylxanthine (IBMX) for $2 \mathrm{~h}$ improved the blastocyst formation in oocytes stimulated by FSH or amphiregulin (AREG). Furthermore, pre-IVM enhanced the expression of the FSH- or AREG-stimulated extracellular matrix-related genes HAS2, TNFAIP6, and PTGS2, and epidermal growth factor (EGF)-like peptide-related genes AREG and EREG. Additionally, preIVM with dbcAMP and IBMX enhanced the expression of $E G F R$, and also increased and prolonged cumulus cell-oocyte gap junctional communication. The improved oocyte development observed using the pre-IVM protocol was ablated by an EGF receptor phosphorylation inhibitor. These results indicate that pre-IVM with cAMP modulators could contribute to the acquisition of developmental competence by bovine oocytes from small antral follicles through the modulation of EGF receptor signaling and oocyte-cumulus/cumulus-cumulus gap junctional communication.
\end{abstract}

Key words: Bovine, EGFR signaling, Embryo development, Gap junction, Pre-IVM

(J. Reprod. Dev. 64: 233-241, 2018)

S ignals from the somatic compartment of ovarian follicles, such as from granulosa and cumulus cells, regulate oocyte developmental competence, which is defined as the capacity to support fertilization, pre-implantation phases of embryo development, and full-term development [1]. The somatic compartment is under the control of gonadotropins (follicle-stimulating hormone [FSH] and luteinizing hormone $[\mathrm{LH}]$ ), which interact with the local growth factors and steroids during folliculogenesis [1].

During the antral stage of folliculogenesis, prior to the surge in gonadotrophin levels, FSH binds to the FSH receptor and modifies the follicular somatic cells that participate in the acquisition of oocyte competence, meiotic maturation and ovulation. The expression of LH and epidermal growth factor (EGF) receptors on follicular somatic cells is a well-characterized action exerted by FSH $[2,3]$. Furthermore, FSH sustains gap junctional communication (GJC) among the follicular

Received: January 15, 2018

Accepted: February 19, 2018

Published online in J-STAGE: March 2, 2018

(C)2018 by the Society for Reproduction and Development

Correspondence: S Sugimura (e-mail: satoshis@cc.tuat.ac.jp)

This is an open-access article distributed under the terms of the Creative Commons Attribution Non-Commercial No Derivatives (by-nc-nd) License. (CC-BY-NC-ND 4.0: https://creativecommons.org/licenses/by-nc-nd/4.0/) somatic cells as well as between the oocyte and cumulus cells [4], probably via cyclic adenosine monophosphate (cAMP)-protein kinase A (PKA) signaling [5]. GJC enables the passage of cAMP, cyclic guanosine monophosphate (cGMP), metabolites, exosomes, and potentially RNAs, into the oocytes, thereby playing a crucial role in the regulation of meiosis and oocyte competence [6-8]. During the ovulatory cascade, expression of the EGF-like peptides such as amphiregulin (AREG), epiregulin (EREG), and betacellulin (BTC) on mural granulosa cells is induced in rapid response to the FSH and LH surges; thereafter, the EGF-like peptides, cleaved and released from the cell surface by ectodomain sheddases such as ADAM metallopeptidase domain 17 (ADAM17), activate the EGFR on cumulus cells [9-11]. EGFR signaling stimulates expression of the extracellular matrix-related genes, such as hyaluronan synthase 2 (HAS2), tumor necrosis factor alpha-induced protein 6 (TNFAIPO), and prostaglandin-endoperoxide synthase 2 (PTGS2) that enables cumulus expansion essential for ovulation and oocyte capture by the infundibulum, in cooperation with signalling by the potent oocytesecreted factors (OSFs), primarily bone morphogenetic protein 15 (BMP15), growth differentiation factor 9 (GDF9), and the BMP15/ GDF9 heterodimer cumulin [12-14].

Oocytes gradually acquire developmental competence during folliculogenesis [15]. Hence, oocytes from small antral follicles 
have lower competence to reach the blastocyst stage compared to those from large follicles [16-19]. In an experimental pig model, the cumulus-oocyte complexes (COCs) derived from small antral follicles possess less competence for cumulus expansion, in response to EGF or EGF-like peptides, partly because of immature EGFR signaling in cumulus cells [20-22]. This could possibly account for the low developmental competence of oocytes from small antral follicles. Hence, promotion of EGFR signaling in cumulus cells seems to be a key factor in the acquisition of oocyte developmental competence [21-23].

The proportion of bovine oocytes exhibiting developmental competence greatly increases in follicles $>6 \mathrm{~mm}$ (medium-large antral) [24]. While some oocytes in 3-mm follicles (small antral) do possess a certain degree of developmental competence, they require additional "capacitation" or "pre-maturation" in vivo prior to the final maturation triggered by the surge in gonadotrophin levels to induce competence $[25,26]$. Pre-maturation in vivo can be driven by advancing follicular growth with exogenous FSH priming; the oocytes derived from cows, treated with FSH prior to ovum pick up (OPU), have higher developmental competence than those derived from untreated cows [27-29]. Recently, we showed that FSH-priming in vivo, prior to oocyte retrieval, drastically modulates gene expression in the cumulus cells, particularly in relation to increased cell-cell communication, and enhances the responsiveness of cumulus cells to the EGF-like peptides, which are implicated in the acquisition of oocyte developmental competence [29].

Despite the fact that oocyte developmental competence is enhanced by FSH-priming, there are notable practical limitations in the process of FSH administration to animals/women: in cattle oocytes cannot be collected constantly, in comparison with conventional OPU without FSH-priming (non-stimulated or FSH-stimulated OPU sessions can be performed four times versus once in two weeks, respectively) [30], and the cost of embryo production is increased by the hormonal treatment. Moreover, depending on the environment and protocols [31], the herd invariably contains poor responders to FSH. Furthermore, when using slaughterhouse-derived ovaries, it is normal to collect ovaries from FSH-unprimed animals where mostly small antral follicles dominate. Therefore, it is highly desirable to develop an "in vitro pre-maturation" protocol (pre-IVM) that mimics as best as possible FSH administration prior to final oocyte maturation.

Along with other researchers, we have demonstrated that increasing COC cAMP levels, through pre-IVM with cAMP modulators, leads to greater oocyte developmental competence [32-39]. In the present study, our aim was to analyze the participation of pre-IVM with cAMP modulators in the enhancement of EGFR signaling and cell-cell communication in cumulus cells, which are typically important for the acquisition of oocyte developmental competence [40]. Firstly, we examined the interactive effect of pre-IVM with established cAMP modulators, such as N6,2'-O-dibutyryladenosine 3',5'-cyclic monophosphate (dbcAMP) and 3-isobutyl-1-methylxanthine (IBMX), and FSH/AREG on the in vitro development of bovine oocytes derived from small antral follicles (2- to 4-mm). Subsequently, we examined the effect of cAMP-modulated pre-IVM on FSH/AREG-induced cumulus expansion and its related genes such as HAS2, TNFAIP6, and $P T G S 2$ and EGF-like peptide-encoding gene expression such as $A R E G, E R E G$ and $B T C$. Finally, the effects of cAMP modulators on $E G F R$ expression and GJC were analyzed.

\section{Materials and Methods}

\section{Chemicals}

Unless specified, all chemicals were purchased from Sigma-Aldrich (St Louis, MO, US).

\section{Animal care and use}

This study was approved by the Ethics Committee for the Care and Use of Experimental Animals at Tokyo University of Agriculture and Technology, Tokyo, Japan.

\section{Oocyte collection}

Ovaries from Japanese Black or Japanese Black $\times$ Holstein breeds were collected from a local slaughter house, transported to the laboratory, washed, and stored in physiological saline. COCs were aspirated from small antral follicles (2-4 $\mathrm{mm}$ in diameter), using a 10 -ml syringe equipped with a 19-gauge needle.

\section{Pre-in vitro maturation}

Depending on the experimental design (Fig. 1), immature COCs were cultured in HEPES-buffered TCM199 supplemented with 4 $\mathrm{mg} / \mathrm{mL}$ of fatty-acid free bovine serum albumin (BSA) and $0.5 \mathrm{mM}$ pyruvate (IVM medium), $+/-1 \mathrm{mM}$ dbcAMP and $500 \mu \mathrm{M}$ IBMX, for $2 \mathrm{~h}$ during the pre-IVM period [21, 32, 39]. In a preliminary study, COCs were treated with either $1 \mathrm{mM}$ dbcAMP and $500 \mu \mathrm{M}$ IBMX or $100 \mu \mathrm{M}$ forskolin (FSK) and $500 \mu \mathrm{M}$ IBMX for $2 \mathrm{~h}$, and then cultured in FSH-supplemented IVM medium for $22 \mathrm{~h}$.

\section{In vitro maturation}

The IVM medium was HEPES-buffered TCM 199 supplemented with $4 \mathrm{mg} / \mathrm{ml}$ of fatty-acid free BSA, $0.5 \mathrm{mM}$ pyruvate, and no hormones (control), or $0.1 \mathrm{IU} / \mathrm{ml} \mathrm{FSH} \mathrm{(Follistim;} \mathrm{MSD,} \mathrm{Tokyo,}$ Japan) or $100 \mathrm{ng} / \mathrm{ml}$ recombinant human amphiregulin (AREG; R\&D systems, Minneapolis, MN). These doses of FSH and AREG are based on previous studies $[7,29]$ demonstrating maximal benefit on oocyte developmental competence. Compacted COCs with $>3$ layers of cumulus cells and a homogeneous ooplasm were washed twice with the IVM medium and cultured in $100 \mu$ IVM medium covered with paraffin oil (Paraffin Liquid; Nacalai Tesuque, Kyoto, Japan) in $35-\mathrm{mm}$ Petri dishes at $38.5^{\circ} \mathrm{C}$ in humidified atmosphere having $5 \% \mathrm{CO}_{2}$ for $22 \mathrm{~h}$.

\section{COC expansion assay}

Cumulus expansion assay was performed as described earlier [41]. The expansion was scored at $22 \mathrm{~h}$ of IVM. Degree of cumulus expansion was scored between 0 to +4 . A score of 0 indicated no detectable response, +1 indicated a minimal response (with cells in the peripheral two layers beginning to expand), +2 indicated an expansion extending inwards to several layers, +3 indicated an expansion of all cumulus layers (except the corona radiata cells), and +4 indicated an expansion of the entire cumulus including the corona radiate cells. 
IVM

IVM medium +/- FSH/AREG

Standard IVM
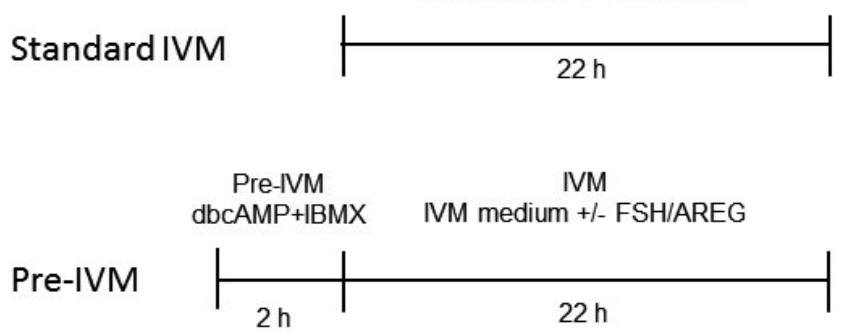

Fig. 1. Schematic representation of the experimental design. COCs were cultured in IVM medium with/without $0.1 \mathrm{IU} / \mathrm{ml} \mathrm{FSH}$ or 100 $\mathrm{ng} / \mathrm{ml}$ AREG for $22 \mathrm{~h}$ (Standard IVM). As another experimental group, COCs were cultured in IVM medium with/without FSH and AREG after pre-IVM with/without $1 \mathrm{mM}$ dbcAMP and 500 $\mu \mathrm{M}$ IBMX for $2 \mathrm{~h}$ (Pre-IVM).

In vitro fertilization (IVF)

IVF was performed as reported previously [42]. Post IVM, the ejaculated sperm samples from Japanese black bulls were thawed and centrifuged in $3 \mathrm{ml}$ of $90 \%$ Percoll solution (GE Healthcare, Uppsala, Sweden) at $750 \times g$ for $10 \mathrm{~min}$. After centrifugation, the pellet was re-suspended and centrifuged in $6 \mathrm{ml}$ of sperm-washing solution (Brackett and Oliphant solution, BO) [43], supplemented with $10 \mathrm{mM}$ hypotaurine and $4 \mathrm{U} / \mathrm{ml}$ heparin (Novo-Heparin Injection 1000; Aventis Pharma, Tokyo, Japan) at $550 \times \mathrm{g}$ for $5 \mathrm{~min}$. The pellet was then re-suspended in sperm-washing solution and BO solution, supplemented with $20 \mathrm{mg} / \mathrm{ml}$ BSA to achieve a final concentration of $3 \times 10^{6} \mathrm{sperm} / \mathrm{ml}$. Droplets (100 $\mu$ l each) of this suspension were aliquoted in 35-mm dishes under paraffin oil as fertilization droplets. COCs were washed twice in BO (supplemented with $10 \mathrm{mg} / \mathrm{ml} \mathrm{BSA}$ ) and cultured in the fertilization droplets for $6 \mathrm{~h}$ at $38.5^{\circ} \mathrm{C}$ and $5 \%$ $\mathrm{CO}_{2}$ with saturated humidity.

In vitro culture (IVC)

Charles Rosenkrans 1 medium with amino acids (CR1aa) supplemented with $5 \%$ calf serum was used as the IVC medium [44]. IVC of embryos was performed at $38.5^{\circ} \mathrm{C}$ in $5 \% \mathrm{O}_{2}, 5 \% \mathrm{CO}_{2}$, and $90 \% \mathrm{~N}_{2}$, with saturated humidity, for 7 days in $100 \mu$ IVC medium droplets.

\section{Real-time RT-PCR analysis}

Real-time RT-PCR analysis was performed as previously described [29]. Cumulus cells were removed from immature COCs by pipetting with a grass pipette. Cumulus cells were lysed in $300 \mu \mathrm{l}$ of RTL buffer containing $10 \mu \mathrm{l} / \mathrm{ml}$ of 2 -mercaptoethanol and stored at $-80^{\circ} \mathrm{C}$. Total RNA was extracted from each sample using the RNeasy Micro Kit (Qiagen, CA). Genomic DNA was removed by recombinant RNase-free DNase I digestion (Qiagen). RNA was quantified using a NanoDrop spectrophotometer (Thermo Fisher Scientific, MA). Total RNA (200 ng), extracted from cumulus cells from 30 COCs, was reverse transcribed with random primers (Invitrogen, CA) using Super-Script III (Invitrogen). The real-time PCR analysis was performed on a StepOne ${ }^{\mathrm{TM}}$ instrument (Applied Biosystems, Foster City, CA) in a $20-\mu 1$ reaction volume containing $3 \mu \mathrm{l}$ cDNA, $2.5 \mu 1$ each of forward and reverse primers (Table 1), $2 \mu 1$ nucleasefree water, and $10 \mu 1$ of SYBR Green PCR Master Mix (Applied Biosystems). PCRs were performed in duplicate. Universal thermal cycling parameters (initial step of $2 \mathrm{~min}$ at $50^{\circ} \mathrm{C}$ and $10 \mathrm{~min}$ at $95^{\circ} \mathrm{C}$, followed by 40 cycles of $15 \mathrm{sec}$ at $95^{\circ} \mathrm{C}$ and $60 \mathrm{sec}$ at $60^{\circ} \mathrm{C}$ ) were used. Melting curve analysis was carried out on the real-time

Table 1. Sequences of primers used for real-time RT-PCR

\begin{tabular}{|c|c|c|c|}
\hline Gene name & GenBank accession number & Primer sequences forward $(F)$ and reverse $(R)$ & Amplicon size (bp) \\
\hline RPL17 & NM_001040516.1 & $\begin{array}{l}\text { F: 5'- TGAGGCCCGCAGGTCTAAG-3' } \\
\text { R: 5'- CTTCCTCCTTGGACAGAGTCTTG-3' }\end{array}$ & 101 \\
\hline HAS 2 & NM_17407.2 & $\begin{array}{l}\text { F: 5'- GGATCTCCTTCCTCAGCAGTGT-3' } \\
\text { R: 5'- ATTCCCAGAGGTCCGCTAATG-3' }\end{array}$ & 106 \\
\hline TNFAIP6 & NM_001007813.2 & $\begin{array}{l}\text { F: 5'- TGAAAGATGGGATGCATATTGC-3' } \\
\text { R: 5'- CATTTGGGAAGCCTGGAGATT-3' }\end{array}$ & 101 \\
\hline PTGS2 & NM_174445.2 & $\begin{array}{l}\text { F: 5'- CTTAAACAAGAGCATCCAGAATGG-3' } \\
\text { R: 5'- GCTGTACGTAGTCTTCAATCACAATCT-3', }\end{array}$ & 101 \\
\hline$A R E G$ & NM_001099092.1 & $\begin{array}{l}\text { F: 5'-CTTTCGTCTCTGCCATGACCTT-3' } \\
\text { R: 5'-CGTTCTTCAGCGACACCTTCA-3' }\end{array}$ & 100 \\
\hline EREG & XM_010797936.2 & $\begin{array}{l}\text { F: 5'-ACTGCACAGCATTAGTTCAAACTGA-3' } \\
\text { R: 5'-TGTCCATGCAAACAGTAGCCATT-3' }\end{array}$ & 100 \\
\hline$B T C$ & NM_173896.2 & $\begin{array}{l}\text { F: 5'-GCCCCAAGCAGTACAAGCAT-3' } \\
\text { R: 5'-GCCCCAGCATAGCCTTCATC-3' }\end{array}$ & 100 \\
\hline ADAMI7 & XM_595713.8 & $\begin{array}{l}\text { F: 5'-TGGGATGTGAAGATGTTGCTAGA-3' } \\
\text { R: 5'-ATCCAAGTGTTCCCATATCAAAATC-3' }\end{array}$ & 105 \\
\hline$E G F R$ & XM_592211.8 & $\begin{array}{l}\text { F: 5'-ACCACCCATCCTGCCTGTATCAA-3' } \\
\text { R: 5'-TGCCCAAACGGACAACATTCTTCC-3' }\end{array}$ & 481 \\
\hline FSHR & ВT025383.1 & $\begin{array}{l}\text { F: 5'-AGAGCAAGGTGACAGAGATTCC-3' } \\
\text { R:5'- ATGTAGTTTGGGCAGGTTGG-3' }\end{array}$ & 91 \\
\hline
\end{tabular}


Table 2. Comparison of pre-IVM with dbcAMP versus forskolin on oocyte developmental competence

\begin{tabular}{|c|c|c|c|c|c|}
\hline \multirow{3}{*}{ IVM protocol } & \multirow{3}{*}{$\begin{array}{l}\text { No. of cultured embryo } \\
\text { (replicates) }\end{array}$} & \multicolumn{4}{|c|}{ Percentage of embryos (mean \pm SEM $\%)$} \\
\hline & & \multicolumn{2}{|c|}{ Cleavage } & \multicolumn{2}{|c|}{ Blastocyst / Cleavage } \\
\hline & & Total & 4 cells $<$ & Total & Expanded stage \\
\hline Standard IVM * & $91(5)$ & $86.7 \pm 2.5$ & $67.9 \pm 4.6$ & $40.4 \pm 2.2^{b}$ & $29.0 \pm 1.9^{b}$ \\
\hline Pre-IVM with dbcAMP+IBMX ** & $96(5)$ & $90.5 \pm 2.1$ & $70.6 \pm 3.8$ & $62.4 \pm 4.9^{\mathrm{a}}$ & $52.1 \pm 5.5^{\mathrm{a}}$ \\
\hline Pre-IVM with FSK + IBMX $* * *$ & $82(5)$ & $80.7 \pm 3.1$ & $64.5 \pm 6.1$ & $53.2 \pm 2.4^{\mathrm{a}}$ & $32.4 \pm 3.4^{\mathrm{ab}}$ \\
\hline
\end{tabular}

* Cumulus oocyte complexes (COCs) were cultured in FSH-supplemented IVM medium for $22 \mathrm{~h}$. ** COCs were treated with $1 \mathrm{mM}$ dbcAMP and $500 \mu \mathrm{M}$ IBMX for $2 \mathrm{~h}$ and then cultured in FSH-supplemented IVM medium for $22 \mathrm{~h}$. *** COCs were treated with $100 \mu \mathrm{M}$ forskolin (FSK) and $500 \mu \mathrm{M}$ IBMX for $2 \mathrm{~h}$ and then cultured in FSH-supplemented IVM medium for $22 \mathrm{~h}$.

a,b Values are significantly different among IVM protocol $(\mathrm{P}<0.05)$.

cycler to check the specificity of the reaction. A standard curve was generated for the genes in every PCR run by using a serial 5-fold dilution of the amplified cDNA derived from cumulus cells. Final quantitative analysis of each gene was performed using the standard curve method and results were reported relative to the housekeeping gene of ribosomal protein L19 (RPL19).

\section{Gap junctional communication assay}

The degree of gap junctional communication in COCs was assessed using lucifer yellow (LY) dye microinjected into the ooplasm, as previously described [36]. After 0,3 , and 6 h of IVM, 3\% LY in 5 $\mathrm{mM}$ lithium chloride was microinjected into the oocyte. The spread of dye into the surrounding cumulus cells was assessed under a confocal microscope within $15 \mathrm{~min}$ of injection. Individual COCs were scored as +2 when the dye was completely spread over the entire cumulus mass, +1 when the dye was transferred to limited number of cumulus cell layers (just beyond the corona radiata), and 0 when the dye was transferred to only the corona radiata cells or was not transferred to any cumulus cells at all. The average score of 10 COCs in each treatment group was calculated to generate the coupling index.

\section{Statistical analyses}

All data were analyzed using analysis of variance (ANOVA) followed by Tukey-Kramer test with JMP software version 4.0.5 (SASS Institute, Cary, NC, USA). Prior to ANOVA, a KolmogorovSmirnov test and Bartlett's test were used to check normality and homogeneity of variance, respectively. All percentage data were arc-sine transformed prior to ANOVA. For all data, $\mathrm{P}<0.05$ was considered statistically significant.

\section{Results}

Pre-IVM with dbcAMP and IBMX is effective for improving developmental competence of bovine oocytes

The effect of pre-IVM with different types of cAMP moderators (dbcAMP + IBMX versus FSK + IBMX) on oocyte developmental competence was examined (Table 2). Highest yield of total blastocysts and expanded blastocysts were observed using pre-IVM with dbcAMP + IBMX. Hence, this protocol was used as the pre-IVM condition in subsequent analyses.
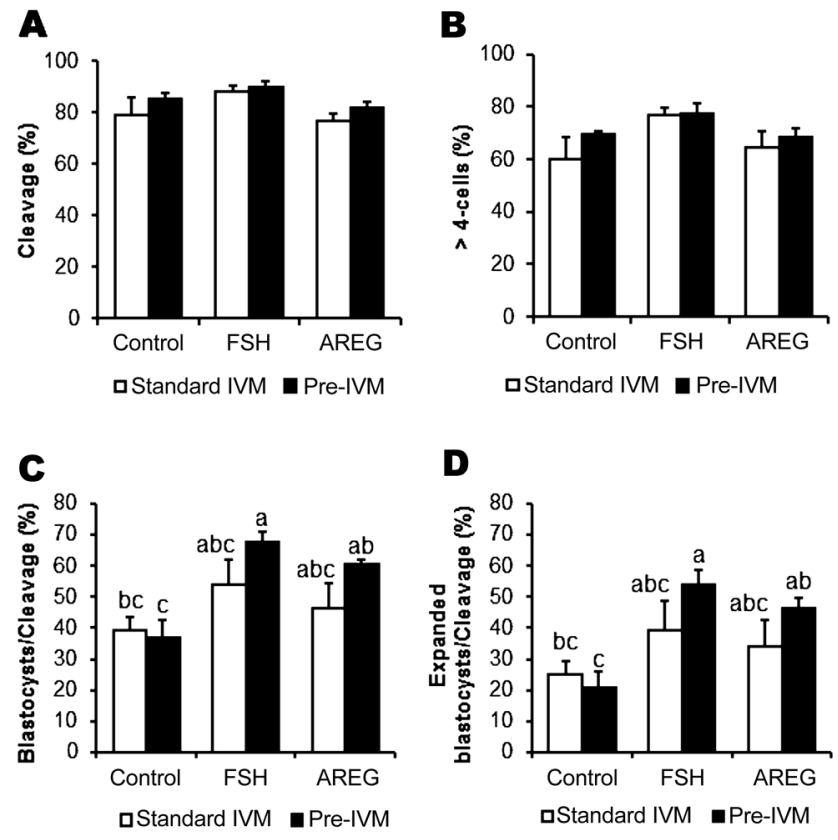

Fig. 2. Effect of pre-IVM on developmental competence of oocytes from COCs unstimulated or stimulated by FSH or AREG. Prior to IVM, COCs were treated with or without dbcAMP and IBMX for $2 \mathrm{~h}$ (Pre-IVM). COCs were then cultured in IVM medium with/ without FSH or AREG (Standard IVM). Effect of treatments on oocyte developmental competence were examined by evaluating the following embryonic developmental milestones: cleaved embryos (A), > 4-cell embryos (B) at day 2 and blastocyst (C) and expanded blastocyst development (D) on day 7. Blastocyst and expanded blastocyst formation rates were expressed as a percentage of cleaved embryos. All values are represented as mean \pm SEM of five replicate experiments. Bars with no common superscript letters are significantly different $(\mathrm{P}<0.05)$.

Pre-IVM with CAMP modulators enhances the developmental competence of oocytes from COCs stimulated by FSH or AREG

We examined the developmental competence of oocytes stimulated by FSH or AREG under conditions of standard IVM or pre-IVM with dbcAMP + IBMX (Fig. 2). There was no significant difference in the rates of cleavage (Fig. 2A) and formation of $>4$-cell embryos (Fig. 2B) among the various treatment groups on day $2(\mathrm{P}>0.05)$. 
A

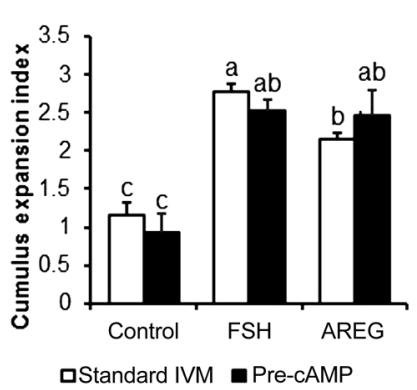

C

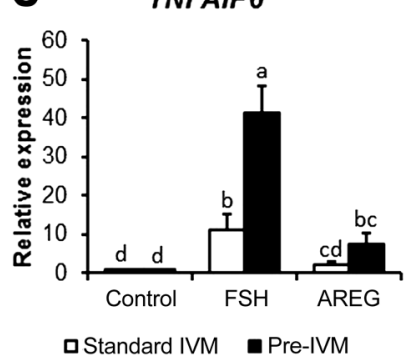

B

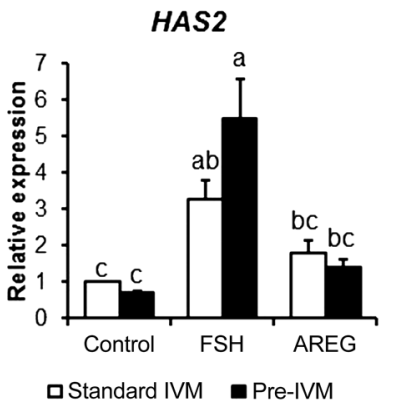

D

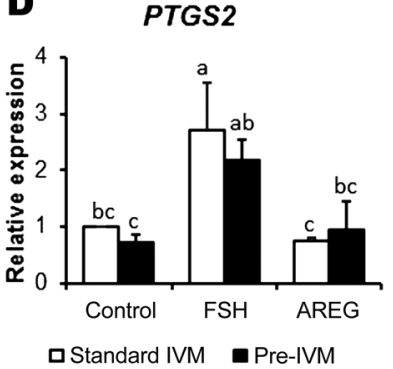

Fig. 3. Cumulus expansion and related mRNA gene expression in FSH or AREG-stimulated/unstimulated cumulus cells under standard IVM conditions, with or without pre-IVM. Cumulus expansion index (A) of COCs was examined after $22 \mathrm{~h}$ of oocyte maturation. All values represent mean \pm SEM of five replicate experiments. Expression of HAS2 (B), TNFIP6 (C) and PTGS2 (D) in cumulus cells of COCs cultured for $6 \mathrm{~h}$ without (control) or with FSH or AREG in standard IVM, with or without pre-IVM. Gene expression was normalized to expression of the housekeeping gene RPL19. The control in the absence of both FSH and AREG was assigned a value of one and all other points are expressed relative to this point. Values represent mean \pm SEM of five replicates. Bars with no common superscript letters indicate significant differences between treatments at $\mathrm{P}<0.05$.

Regarding the rates of formation of total blastocysts (Fig. 2C) and expanded blastocysts (Fig. 2D), significant differences were observed between the control and FSH/AREG-stimulated groups under pre-IVM conditions but not under standard IVM. There was no significant difference between the FSH and AREG groups under conditions of standard IVM or pre-IVM conditions (Fig. 2C and D). These results suggest that pre-treatment with cAMP modulators enhanced the effectiveness of FSH or AREG at improving oocyte developmental competence; achieving blastocyst rates of between $60-70 \%$.

\section{Treatment with cAMP modulators prior to oocyte maturation} enhances the EGF-like peptide-cumulus expansion cascade

Cumulus cell production of extracellular matrix molecules is a hallmark of terminal cumulus cell differentiation and is required for the ovulatory cascade. The expression of key associated genes is mediated by activation of EGFR signaling by the EGF-like peptides [45]. We measured morphological cumulus expansion and the expression of related genes such as $H A S 2, T N F I P 6$, and PTGS2 (Fig. 3), and the

A

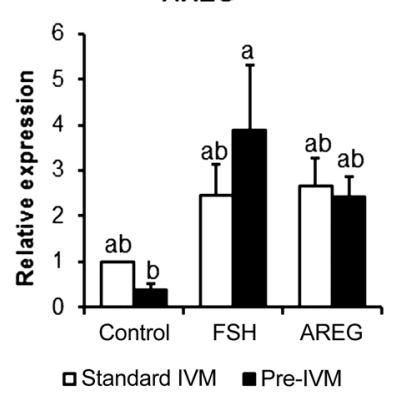

C

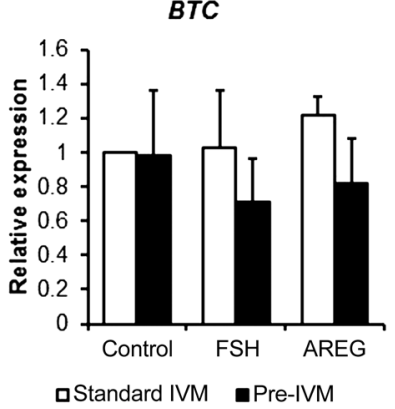

B EREG

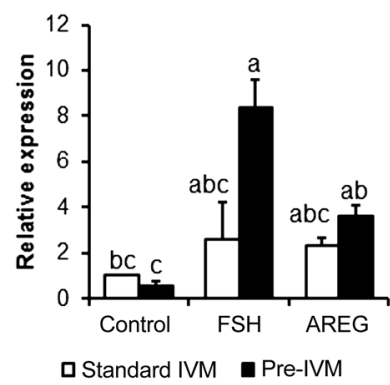

D

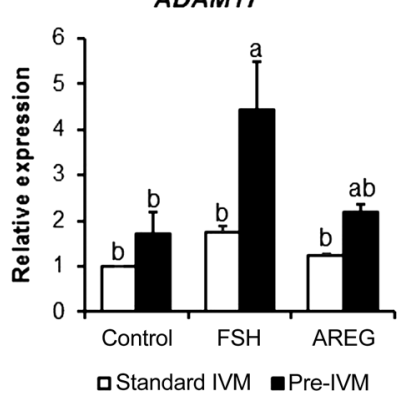

Fig. 4. EGF-like peptide and its sheddase related mRNA gene expression in FSH or AREG stimulated/unstimulated cumulus cells under standard IVM conditions, with or without pre-IVM. Expression of $A R E G(\mathrm{~A}), E R E G(\mathrm{~B}), B T C(\mathrm{C})$ and $A D A M 17$ (D) in cumulus cells of COCs cultured for $6 \mathrm{~h}$ without (control) or with $\mathrm{FSH}$ or AREG in standard IVM, with or without cAMP-modulated pre-IVM. Gene expression was normalized to expression of the housekeeping gene RPL19. The control in the absence of both FSH and AREG was assigned a value of one, and all other points are expressed relative to this point. Values represent mean \pm SEM of five replicates. Bars with no common superscript letters indicate significant differences between treatments at $\mathrm{P}<0.05$.

EGF-like peptide-encoding genes AREG, EREG, and BTC (Fig. 4), in cumulus cells from COCs treated with/without FSH or AREG under conditions of standard IVM or CAMP-modulated pre-IVM. As expected, under standard IVM conditions, cumulus expansion was promoted by both FSH and AREG; however, the level of expansion in AREG-treated COCs was significantly lower than that in FSH-treated COCs (Fig. 3A). On the other hand, under pre-IVM conditions, cumulus expansion was promoted by both FSH and AREG to the same level $(\mathrm{P}>0.05)$. Under conditions of both standard IVM and pre-IVM, FSH but not AREG stimulated HAS2 (Fig. 3B) and PTGS2 expression (Fig. 3D) $(\mathrm{P}<0.05)$. Likewise, TNFAIP6 expression was stimulated by FSH, but not AREG, under standard IVM conditions $(\mathrm{P}<0.05$; Fig. 3C). FSH-stimulated TNFAIP6 expression was further enhanced under pre-IVM conditions $(\mathrm{P}<0.05)$. Although stimulation of TNFIP6 expression by AREG was somewhat induced following pre-IVM, the expression level was significantly lower than that with FSH stimulation (Fig. 3C). Regarding the EGF-like peptide-encoding genes, the expression of $A R E G$ was promoted by FSH stimulation under pre-IVM but not under standard IVM $(\mathrm{P}<0.05)$; however, the expression was not stimulated by AREG in either pre-IVM and 
A

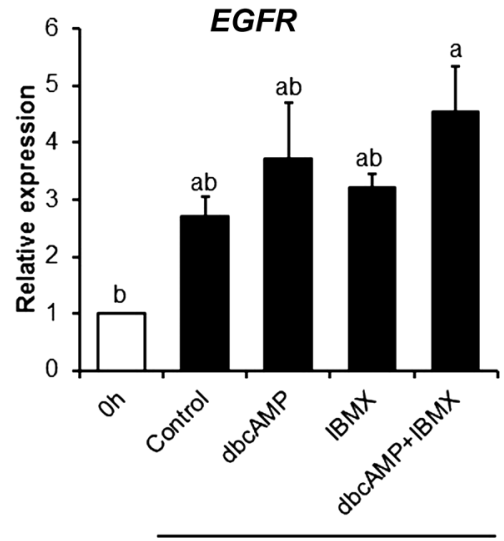

Pre-IVM for $2 \mathrm{~h}$

B

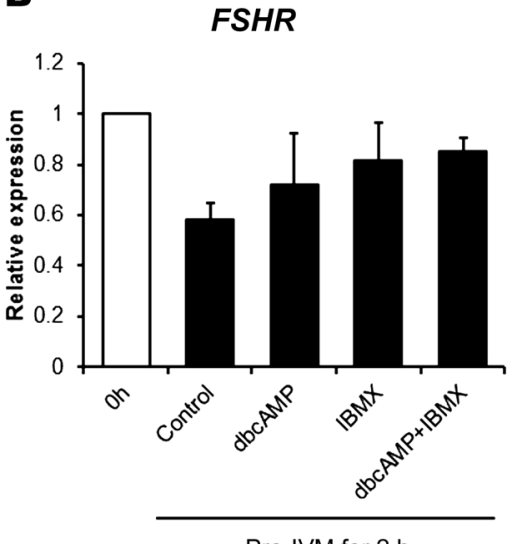

Pre-IVM for $2 \mathrm{~h}$

Fig. 5. Effect of cAMP-modulated pre-IVM on expression of $E G F R$ and FSHR mRNA in cumulus cells. Expression of EGFR (A) and FSHR (B) in cumulus cells from COCs before pre-IVM $(0 \mathrm{~h})$ or after no treatment (control) or treatment with dbcAMP and/or IBMX for $2 \mathrm{~h}$. Gene expression was normalized to expression of the housekeeping gene RPL19. The value at $0 \mathrm{~h}$ was set as one and all other points are expressed relative to this point. Values represent mean \pm SEM of five replicates. Bars with no common superscript letters indicate significant differences between treatments at $\mathrm{P}<0.05$.

standard IVM (P>0.05; Fig. 4A). Pre-IVM led to enhanced EREG expression in response to FSH or AREG, which did not occur under standard IVM conditions ( $\mathrm{P}<0.05$; Fig. 4B). BTC was not stimulated by FSH or AREG under standard IVM or pre-IVM conditions (Fig. 4C). $A D A M 17$, encoding a sheddase for cleaving EGF-like peptides, was stimulated by FSH under pre-IVM but not under standard IVM $(\mathrm{P}<0.05)$, suggesting that pre-IVM with cAMP modulators enhances EGF-like peptide-cumulus expansion cascade following FSH or AREG stimulation.

Pre-IVM with dbcAMP and IBMX increases the expression of EGFR, but not FSHR

We examined the effect of the cAMP moderators; dbcAMP alone,

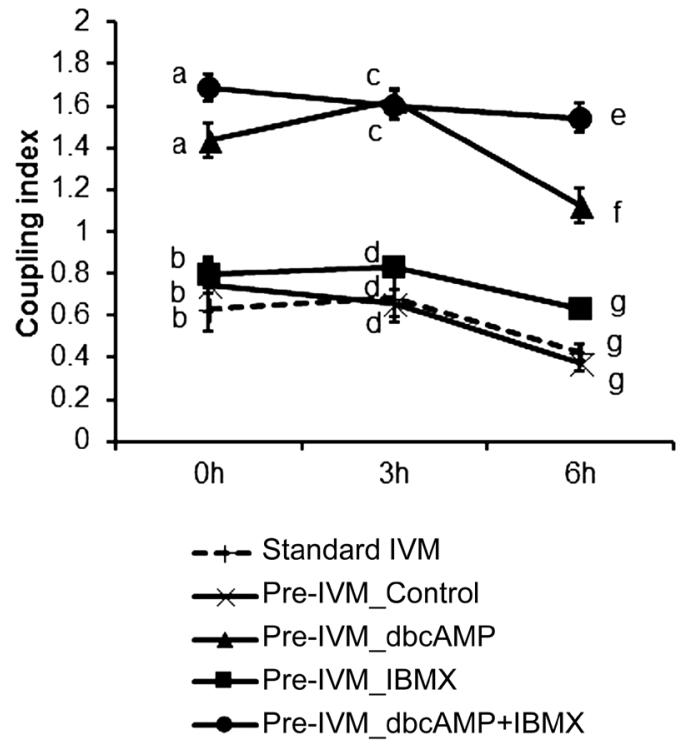

Fig. 6. Regulation of oocyte-cumulus cells/cumulus cells-cumulus cells gap-junctional communication in COCs with standard IVM or pre-IVM conditions. LY diffusion of COCs cultured in IVM medium (Standard IVM) or in IVM medium after pre-IVM without (control) or with dbcAMP and/or IBMX for $2 \mathrm{~h}$ (PreIVM) was examined at 0,3 , and $6 \mathrm{~h}$ of in vitro oocyte maturation, respectively. No ligand was included in the IVM medium. Values represent mean \pm SEM of five replicates. Points with different letters within a time-point indicate significant differences between treatments at $\mathrm{P}<0.05$.

IBMX alone, and dbcAMP + IBMX, on EGFR and FSHR expression by cumulus cells (Fig. 5). Expression of EGFR (Fig. 5A), but not FSHR (Fig. 5B), after pre-IVM for $2 \mathrm{~h}$ was increased by the combination of dbcAMP and IBMX, but not by dbcAMP or IBMX alone $(\mathrm{P}<$ 0.05), suggesting a possible regulation of EGFR expression by cAMP.

\section{Pre-IVM with dbcAMP increases cell-to-cell communication}

Oocyte to cumulus cell and/or cumulus cell to cumulus cell gap junctional communication (GJC) was measured by assessing the transfer of LY dye from the oocyte to the surrounding cumulus vestment at 0,3 , and $6 \mathrm{~h}$ of in vitro maturation under standard IVM conditions or at $6 \mathrm{~h}$ of IVM following pre-IVM with/without dbcAMP or IBMX for $2 \mathrm{~h}$ (Fig. 6). In general, pre-IVM with dbcAMP notably increased oocyte-cumulus cell GJC for the following 6 hours of IVM. At $0 \mathrm{~h}$ of IVM, the coupling index was increased by pre-IVM with dbcAMP alone or dbcAMP + IBMX, compared to that of standard IVM or pre-IVM without cAMP moderators $(\mathrm{P}<0.05)$. Similar findings were observed at 3 and $6 \mathrm{~h}$. However, the coupling index of COCs treated with dbcAMP + IBMX was significantly higher than that of COCs treated with dbcAMP alone at $6 \mathrm{~h}$ of IVM. These results suggest that combined treatment with dbcAMP and IBMX prior to IVM can not only increase but also sustain GJC. 
EGFR signaling triggered by pre-IVM with cAMP modulators participates in oocyte developmental competence

To investigate whether the cAMP-modulated pre-IVM improvements in oocyte competence occur independent of EGFR or are a function of EGFR signaling, we examined the effect of AG1478, a well-known inhibitor of EGFR tyrosine kinase, on oocyte developmental competence. AG significantly decreased the rate of formation of $>4$ cell embryos (Fig. 7B) but not of cleavage (Fig. 7A) in FSH- or AREG-stimulated oocytes. Under conditions of pre-IVM, FSH or AREG generated high blastocyst ( $71 \%$ and $66 \%$, respectively) and expanded blastocyst rates; however, the additive benefit of FSH or AREG was ablated by AG treatment $(\mathrm{P}>0.05$; Fig. $7 \mathrm{C}$ and D). These results suggest that the improved oocyte developmental competence by pre-IVM in FSH- or AREG-stimulated oocytes is likely to result from the effects of pre-IVM with cAMP modulators on EGFR signaling.

\section{Discussion}

Differentiation and development of follicular somatic cells by FSH prior to final oocyte maturation is required for acquisition of oocyte developmental competence $[3,29]$. However, to produce bovine or human IVM embryos, oocytes are usually derived from small antral follicles of FSH-unprimed donors (bovine) or following minimal FSH-stimulation (human). Oocytes from such small antral follicles have low developmental competence for many reasons, not least because of insufficient EGFR signaling in cumulus cells [20-22, 29, 46]. Here, we show that pre-maturation in vitro with cAMP modulators enhanced COC gap junctional communication and EGFR signaling stimulated by FSH or AREG in developing COCs from small antral follicles. This culminated in enhanced developmental competence of bovine oocytes and notable blastocyst yields of $\sim 70 \%$.

As observed in previous studies (reviewed; [40]), upregulation of COC cAMP levels prior to IVM seems to be effective in improving oocyte competence, as this has been shown to significantly improve the subsequent development of bovine [32, 34, 36, 37], porcine $[21,39]$, murine [32, 33, 38], ovine [35], and human IVM oocytes [47]. Consistent with this body of literature, in the current study pre-IVM for $2 \mathrm{~h}$ with cAMP modulators increased the developmental competence of bovine oocytes from small antral follicles. The optimal cAMP modulators for pre-IVM are currently unknown. dbcAMP was the original agent used [39] and is now widely used in porcine IVM protocols (reviewed; [40]). More recently COCs have been treated in pre-IVM with forskolin and IBMX, and this protocol has proven effective in several animal species including bovine, ovine, murine, and in humans. In the present study, we investigated the effect of pre-IVM on subsequent embryo development using the dbcAMP and IBMX and found this pre-IVM protocol effective at increasing blastocyst yield. We used this protocol as we found blastocyst yield to be higher with the dbcAMP + IBMX protocol than with the forskolin + IBMX protocol. Although the optimal pre-IVM duration and modulator concentration have been evaluated, it may be necessary, for each animal species, to optimize the type of cAMP modulator used for pre-IVM as well, as this is likely to affect oocyte developmental competence.

Previously, we reported that establishing functional EGFR signaling
A

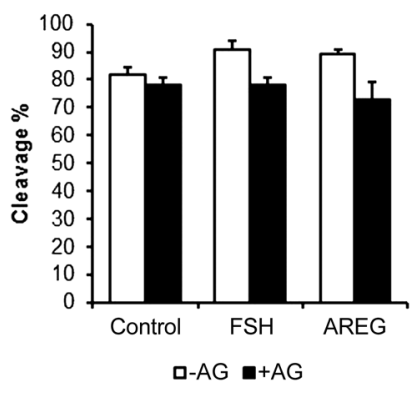

C

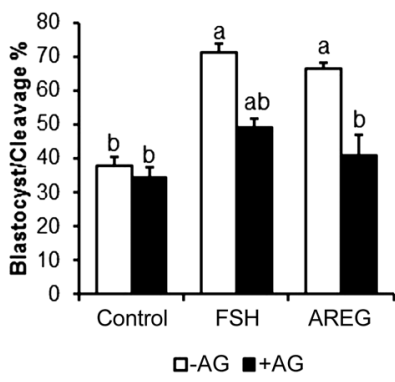

B

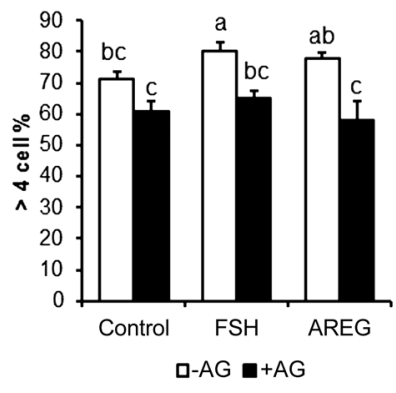

D

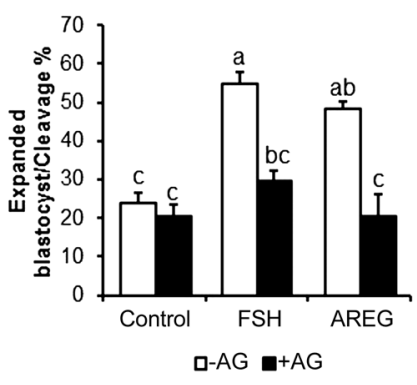

Fig. 7. Effect of EGFR signaling inhibition on developmental competence of oocytes matured following cAMP-modulated pre-IVM. COCs were treated with dbcAMP and IBMX for $2 \mathrm{~h}$ and then cultured in IVM medium supplemented with FSH or AREG, either in the absence (-AG) or presence of $10 \mu \mathrm{M}$ of the EGFR tyrosine kinase inhibitor, AG1478 (+AG). Developmental competence was examined by measuring embryo development at the following time points: cleaved embryos (A), > 4-cell embryos (B) at day 2 and embryos developed to the blastocyst (C) and expanded blastocyst stages (D) at day 7. Blastocyst and expanded blastocyst formation rates are expressed as a percentage of cleaved embryos. Values represent means \pm SEM of five replicates. Bars with no common superscript letters indicate significant differences at $\mathrm{P}<0.05$.

prior to the final ovulation cascade via EGF-like peptides is involved in acquisition of oocyte developmental competence, and that the FSH secondary messenger cAMP, in conjunction with the oocyte-secreted factors, are involved in the acquisition of functional EGFR signaling [21-23]. Furthermore, we recently showed that FSH-priming prior to OPU enhanced the responsiveness of cumulus cells to EGF-like peptides in a bovine model [29]. Other reports also demonstrated that FSH is required for fully functional EGFR signaling [3]. Richani et al. showed that pre-IVM with cAMP modulators significantly increases EGF-like peptide expression following FSH or EGF-like peptide stimulation compared to the standard IVM protocol [38]. However, in bovine small antral follicles, it was not clear whether pre-IVM with cAMP modulators is involved in enhancement of the EGF-like peptide-EGFR signaling axis in cumulus cells. In this study, pre-IVM with cAMP modulators enhanced FSH- or AREG-stimulated cumulus cell EGFR signaling, which was bolstered by an increase in expression of the extracellular matrix-related genes HAS2, TNFIP6 and PTGS2, which are established down-stream molecules of EGFR signaling in mice [45]. This would be linked to increased expression of not only EGF-like peptides and sheddases, but also of EGFR 
encoding genes. In stimulated mice, the expression of EGFR at the end of pre-IVM was not affected by treatment with forskolin + IBMX [38]. This inconsistency may be due to differences in the animal species, the developmental stage of COCs examined, or the type of cAMP modulators used in this study. Although the relationship between FSH and EGFR expression has been demonstrated using Fshb (-/-) mice [3], further studies will be required to clarifying the relationship between cAMP signaling and EGFR expression.

Mechanisms accounting for the increased oocyte developmental competence resulting from pre-IVM with cAMP modulators may include, among others, increased and prolonged cell-to-cell gap junctional communication and enhanced EGFR signaling [40]. Cumulus cell-oocyte gap junctional communication is abruptly terminated during standard IVM, but can be readily prolonged by pre-IVM with elevated cAMP [34, 48, 49]. Premature gap junction closure during standard IVM leads to rapid chromatin condensation and cessation of oocyte RNA transcription; maintenance of this communication using PDE inhibitors, however, can positively alter chromatin remodeling and oocyte transcription, which is related to increased oocyte developmental competence [49]. We also showed that prolonged gap junctional communication between oocytes and cumulus cells alters oocyte metabolites, such as nicotinamide adenine dinucleotide and oxidized flavin adenine dinucleotide, which may be the result of EGF-like peptide stimulation in cumulus cells [7]. Pre-IVM culture with forskolin and IBMX significantly increased oocyte mitochondrial membrane potential and ATP content in mice [33], and increased bovine intra-oocyte glutathione levels in a GJCdependent manner, enabling the oocyte to be more able to resist oxidative stress [34]. A further important consequence of possessing a fully developed EGF-like peptide-EGFR signaling cascade in the COC is translation of stored maternal mRNA transcripts during oocyte maturation, that may be important for oocyte developmental competence [50]. Hence, improved oocyte maturation conditions may facilitate the efficient transport of EGF-like peptide-stimulated metabolites and molecules from cumulus cells into oocytes via gap junctions, and as a result, lead to improved metabolic and translation states in the oocyte.

In conclusion, the present study hypothesized that effective prematuration in vitro with dbcAMP and IBMX could potentially mimic in vivo FSH-priming of animals, which is an effective but nonetheless inefficient means of enhancing oocyte developmental competence and IVM outcomes. Pre-maturation with cAMP modulators seems to be important for priming the oocyte for final oocyte maturation, which involves facilitating cell-to-cell gap junctional communication and functional EGFR signaling, required for developmental competence of bovine oocytes in vitro. This knowledge has significant implications for improving the developmental competence of oocytes derived from small antral follicles of FSH-unprimed animals.

\section{Acknowledgements}

This work was supported by JSPS KAKENHI Grant Numbers JP15K18768 to SS. Authors thank the members of National Livestock Breeding Center for the kind donation of bull sperm.

\section{References}

1. Gilchrist RB, Thompson JG. Oocyte maturation: emerging concepts and technologies to improve developmental potential in vitro. Theriogenology 2007; 67: 6-15. [Medline] [CrossRef]

2. Erickson GF, Wang C, Hsueh AJ. FSH induction of functional LH receptors in granulosa cells cultured in a chemically defined medium. Nature 1979; 279: 336-338. [Medline] [CrossRef]

3. EI-Hayek S, Demeestere I, Clarke HJ. Follicle-stimulating hormone regulates expression and activity of epidermal growth factor receptor in the murine ovarian follicle. Proc Natl Acad Sci USA 2014; 111: 16778-16783. [Medline] [CrossRef]

4. El-Hayek S, Clarke HJ. Follicle-stimulating hormone increases gap junctional communication between somatic and germ-line follicular compartments during murine oogenesis. Biol Reprod 2015; 93: 47. [Medline] [CrossRef]

5. Yun SP, Park SS, Ryu JM, Park JH, Kim MO, Lee JH, Han HJ. Mechanism of PKAdependent and lipid-raft independent stimulation of Connexin 43 expression by oxytoxin in mouse embryonic stem cells. Mol Endocrinol 2012; 26: 1144-1157. [Medline] [CrossRef]

6. Russell DL, Gilchrist RB, Brown HM, Thompson JG. Bidirectional communication between cumulus cells and the oocyte: Old hands and new players? Theriogenology 2016; 86: 62-68. [Medline] [CrossRef]

7. Sugimura S, Ritter LJ, Sutton-McDowall ML, Mottershead DG, Thompson JG, Gilchrist RB. Amphiregulin co-operates with bone morphogenetic protein 15 to increase bovine oocyte developmental competence: effects on gap junction-mediated metabolite supply. Mol Hum Reprod 2014; 20: 499-513. [Medline] [CrossRef]

8. Macaulay AD, Gilbert I, Caballero J, Barreto R, Fournier E, Tossou P, Sirard MA, Clarke HJ, Khandjian EW, Richard FJ, Hyttel P, Robert C. The gametic synapse: RNA transfer to the bovine oocyte. Biol Reprod 2014; 91: 90. [Medline] [CrossRef]

9. Hsieh M, Lee D, Panigone S, Horner K, Chen R, Theologis A, Lee DC, Threadgill DW, Conti M. Luteinizing hormone-dependent activation of the epidermal growth factor network is essential for ovulation. Mol Cell Biol 2007; 27: 1914-1924. [Medline] [CrossRef]

10. Park JY, Su YQ, Ariga M, Law E, Jin SL, Conti M. EGF-like growth factors as mediators of LH action in the ovulatory follicle. Science 2004; 303: 682-684. [Medline] [CrossRef]

11. Shimada M, Hernandez-Gonzalez I, Gonzalez-Robayna I, Richards JS. Paracrine and autocrine regulation of epidermal growth factor-like factors in cumulus oocyte complexes and granulosa cells: key roles for prostaglandin synthase 2 and progesterone receptor. $\mathrm{Mol}$ Endocrinol 2006; 20: 1352-1365. [Medline] [CrossRef]

12. Yoshino O, McMahon HE, Sharma S, Shimasaki S. A unique preovulatory expression pattern plays a key role in the physiological functions of BMP-15 in the mouse. Proc Natl Acad Sci USA 2006; 103: 10678-10683. [Medline] [CrossRef]

13. Mottershead DG, Sugimura S, Al-Musawi SL, Li JJ, Richani D, White MA, Martin GA, Trotta AP, Ritter LJ, Shi J, Mueller TD, Harrison CA, Gilchrist RB. Cumulin, an oocyte-secreted heterodimer of the transforming growth factor- $\beta$ family, is a potent activator of granulosa cells and improves oocyte quality. J Biol Chem 2015; 290: 24007-24020. [Medline] [CrossRef]

14. Sasseville M, Ritter LJ, Nguyen TM, Liu F, Mottershead DG, Russell DL, Gilchrist RB. Growth differentiation factor 9 signaling requires ERK1/2 activity in mouse granulosa and cumulus cells. J Cell Sci 2010; 123: 3166-3176. [Medline] [CrossRef]

15. Eppig JJ, Schroeder AC, O'Brien MJ. Developmental capacity of mouse oocytes matured in vitro: effects of gonadotrophic stimulation, follicular origin and oocyte size. $J$ Reprod Fertil 1992; 95: 119-127. [Medline] [CrossRef]

16. Bagg MA, Nottle MB, Armstrong DT, Grupen CG. Relationship between follicle size and oocyte developmental competence in prepubertal and adult pigs. Reprod Fertil Dev 2007; 19: 797-803. [Medline] [CrossRef]

17. Eppig JJ, Schultz RM, O'Brien M, Chesnel F. Relationship between the developmental programs controlling nuclear and cytoplasmic maturation of mouse oocytes. Dev Biol 1994; 164: 1-9. [Medline] [CrossRef]

18. Lonergan P, Monaghan P, Rizos D, Boland MP, Gordon I. Effect of follicle size on bovine oocyte quality and developmental competence following maturation, fertilization, and culture in vitro. Mol Reprod Dev 1994; 37: 48-53. [Medline] [CrossRef]

19. Marchal R, Vigneron C, Perreau C, Bali-Papp A, Mermillod P. Effect of follicular size on meiotic and developmental competence of porcine oocytes. Theriogenology 2002; 57: 1523-1532. [Medline] [CrossRef]

20. Prochazka R, Kalab P, Nagyova E. Epidermal growth factor-receptor tyrosine kinase activity regulates expansion of porcine oocyte-cumulus cell complexes in vitro. Biol Reprod 2003; 68: 797-803. [Medline] [CrossRef]

21. Sugimura S, Ritter LJ, Rose RD, Thompson JG, Smitz J, Mottershead DG, Gilchrist RB. Promotion of EGF receptor signaling improves the quality of low developmental competence oocytes. Dev Biol 2015; 403: 139-149. [Medline] [CrossRef] 
22. Ritter LJ, Sugimura S, Gilchrist RB. Oocyte induction of EGF responsiveness in somatic cells is associated with the acquisition of porcine oocyte developmental competence. Endocrinology 2015; 156: 2299-2312. [Medline] [CrossRef]

23. Richani D, Gilchrist RB. The epidermal growth factor network: role in oocyte growth, maturation and developmental competence. Hum Reprod Update 2018; 24: 1-14. [Medline] [CrossRef]

24. Caixeta ES, Ripamonte P, Franco MM, Junior JB, Dode MA. Effect of follicle size on mRNA expression in cumulus cells and oocytes of Bos indicus: an approach to identify marker genes for developmental competence. Reprod Fertil Dev 2009; 21: 655-664. [Medline] [CrossRef]

25. Hendriksen PJ, Vos PL, Steenweg WN, Bevers MM, Dieleman SJ. Bovine follicular development and its effect on the in vitro competence of oocytes. Theriogenology 2000; 53: 11-20. [Medline] [CrossRef]

26. Hyttel P, Fair T, Callesen H, Greve T. Oocyte growth, capacitation and final maturation in cattle. Theriogenology 1997; 47: 23-32. [CrossRef]

27. Sirard MA, Picard L, Dery M, Coenen K, Blondin P. The time interval between FSH administration and ovarian aspiration influences the development of cattle oocytes. Theriogenology 1999; 51: 699-708. [Medline] [CrossRef]

28. Sugimura S, Kobayashi S, Hashiyada Y, Ohtake M, Kaneda M, Yamanouchi T, Matsuda H, Aikawa Y, Watanabe S, Nagai T, Kobayashi E, Konishi K, Imai K. Follicular growth-stimulated cows provide favorable oocytes for producing cloned embryos. Cell Reprogram 2012; 14: 29-37. [Medline] [CrossRef]

29. Sugimura S, Kobayashi N, Okae H, Yamanouchi T, Matsuda H, Kojima T, Yajima A, Hashiyada Y, Kaneda M, Sato K, Imai K, Tanemura K, Arima T, Gilchrist RB. Transcriptomic signature of the follicular somatic compartment surrounding an oocyte with high developmental competence. Sci Rep 2017; 7: 6815. [Medline] [CrossRef]

30. De Roover R, Feugang JM, Bols PE, Genicot G, Hanzen C. Effects of ovum pick-up frequency and FSH stimulation: a retrospective study on seven years of beef cattle in vitro embryo production. Reprod Domest Anim 2008; 43: 239-245. [Medline] [CrossRef]

31. Durocher J, Morin N, Blondin P. Effect of hormonal stimulation on bovine follicular response and oocyte developmental competence in a commercial operation. Theriogenology 2006; 65: 102-115. [Medline] [CrossRef]

32. Albuz FK, Sasseville M, Lane M, Armstrong DT, Thompson JG, Gilchrist RB. Simulated physiological oocyte maturation (SPOM): a novel in vitro maturation system that substantially improves embryo yield and pregnancy outcomes. Hum Reprod 2010; 25: 2999-3011. [Medline] [CrossRef]

33. Zeng HT, Richani D, Sutton-McDowall ML, Ren Z, Smitz JE, Stokes Y, Gilchrist RB, Thompson JG. Prematuration with cyclic adenosine monophosphate modulators alters cumulus cell and oocyte metabolism and enhances developmental competence of in vitro-matured mouse oocytes. Biol Reprod 2014; 91: 47. [Medline] [CrossRef]

34. Li HJ, Sutton-McDowall ML, Wang X, Sugimura S, Thompson JG, Gilchrist RB. Extending prematuration with cAMP modulators enhances the cumulus contribution to oocyte antioxidant defence and oocyte quality via gap junctions. Hum Reprod 2016; 31: 810-821. [Medline] [CrossRef]

35. Rose RD, Gilchrist RB, Kelly JM, Thompson JG, Sutton-McDowall ML. Regulation of sheep oocyte maturation using cAMP modulators. Theriogenology 2013; 79: 142-148. [Medline] [CrossRef]

36. Luciano AM, Modina S, Vassena R, Milanesi E, Lauria A, Gandolfi F. Role of intracellular cyclic adenosine 3,5-monophosphate concentration and oocyte-cumulus cells communications on the acquisition of the developmental competence during in vitro maturation of bovine oocyte. Biol Reprod 2004; 70: 465-472. [Medline] [CrossRef]

37. Guixue Z, Luciano AM, Coenen K, Gandolfi F, Sirard MA. The influence of cAMP before or during bovine oocyte maturation on embryonic developmental competence. Theriogenology 2001; 55: 1733-1743. [Medline] [CrossRef]

38. Richani D, Wang X, Zeng HT, Smitz J, Thompson JG, Gilchrist RB. Pre-maturation with cAMP modulators in conjunction with EGF-like peptides during in vitro maturation enhances mouse oocyte developmental competence. Mol Reprod Dev 2014; 81: 422-435. [Medline] [CrossRef]

39. Funahashi H, Cantley TC, Day BN. Synchronization of meiosis in porcine oocytes by exposure to dibutyryl cyclic adenosine monophosphate improves developmental competence following in vitro fertilization. Biol Reprod 1997; 57: 49-53. [Medline] [CrossRef]

40. Gilchrist RB, Luciano AM, Richani D, Zeng HT, Wang X, Vos MD, Sugimura S, Smitz J, Richard FJ, Thompson JG. Oocyte maturation and quality: role of cyclic nucleotides. Reproduction 2016; 152: R143-R157. [Medline] [CrossRef]

41. Vanderhyden BC, Caron PJ, Buccione R, Eppig JJ. Developmental pattern of the secretion of cumulus expansion-enabling factor by mouse oocytes and the role of oocytes in promoting granulosa cell differentiation. Dev Biol 1990; 140: 307-317. [Medline] [CrossRef]

42. Sugimura S, Akai T, Hashiyada Y, Somfai T, Inaba Y, Hirayama M, Yamanouchi T, Matsuda H, Kobayashi S, Aikawa Y, Ohtake M, Kobayashi E, Konishi K, Imai K. Promising system for selecting healthy in vitro-fertilized embryos in cattle. PLOS ONE 2012; 7: e36627. [Medline] [CrossRef]

43. Brackett BG, Oliphant G. Capacitation of rabbit spermatozoa in vitro. Biol Reprod 1975; 12: 260-274. [Medline] [CrossRef]

44. Rosenkrans CF Jr, Zeng GQ, MCNamara GT, Schoff PK, First NL. Development of bovine embryos in vitro as affected by energy substrates. Biol Reprod 1993; 49: 459-462. [Medline] [CrossRef]

45. Conti M, Hsieh M, Zamah AM, Oh JS. Novel signaling mechanisms in the ovary during oocyte maturation and ovulation. Mol Cell Endocrinol 2012; 356: 65-73. [Medline] [CrossRef]

46. Richani D, Ritter LJ, Thompson JG, Gilchrist RB. Mode of oocyte maturation affects EGF-like peptide function and oocyte competence. Mol Hum Reprod 2013; 19: 500-509. [Medline] [CrossRef]

47. Zeng HT, Ren Z, Guzman L, Wang X, Sutton-McDowall ML, Ritter LJ, De Vos M, Smitz J, Thompson JG, Gilchrist RB. Heparin and cAMP modulators interact during pre-in vitro maturation to affect mouse and human oocyte meiosis and developmental competence. Hum Reprod 2013; 28: 1536-1545. [Medline] [CrossRef]

48. Thomas RE, Armstrong DT, Gilchrist RB. Bovine cumulus cell-oocyte gap junctiona communication during in vitro maturation in response to manipulation of cell-specific cyclic adenosine 3,5-monophosophate levels. Biol Reprod 2004; 70: 548-556. [Medline] [CrossRef]

49. Luciano AM, Franciosi F, Modina SC, Lodde V. Gap junction-mediated communications regulate chromatin remodeling during bovine oocyte growth and differentiation through cAMP-dependent mechanism(s). Biol Reprod 2011; 85: 1252-1259. [Medline] [CrossRef]

50. Chen J, Torcia S, Xie F, Lin CJ, Cakmak H, Franciosi F, Horner K, Onodera C, Song JS, Cedars MI, Ramalho-Santos M, Conti M. Somatic cells regulate maternal mRNA translation and developmental competence of mouse oocytes. Nat Cell Biol 2013; 15: 1415-1423. [Medline] [CrossRef] 